\title{
Seizing an opportunity: increasing use of cessation services following a tobacco tax increase
}

\author{
Paula A Keller ${ }^{1 *}$, Lija O Greenseid ${ }^{2}$, Matthew Christenson², Raymond G Boyle ${ }^{1}$ and Barbara A Schillo
}

\begin{abstract}
Background: Tobacco tax increases are associated with increases in quitline calls and reductions in smoking prevalence. In 2013, ClearWay Minnesota ${ }^{\text {SM }}$ conducted a six-week media campaign promoting QUITPLAN` Services (QUITPLAN Helpline and quitplan.com) to leverage the state's tax increase. The purpose of this study was to ascertain the association of the tax increase and media campaign on call volumes, web visits, and enrollments in QUITPLAN Services.
\end{abstract}

Methods: In this observational study, call volume, web visits, enrollments, and participant characteristics were analyzed for the periods June-August 2012 and June-August 2013. Enrollment data and information about media campaigns were analyzed using multivariate regression analysis to determine the association of the tax increase on QUITPLAN Services while controlling for media.

Results: There was a 160\% increase in total combined calls and web visits, and an $81 \%$ increase in enrollments in QUITPLAN Services. Helpline call volumes and enrollments declined back to prior year levels approximately six weeks after the tax increase. Visits to and enrollments in quitplan.com also declined, but increased again in mid-August. The tax increase and media explained over $70 \%$ of variation in enrollments in the QUITPLAN Helpline, with media explaining $34 \%$ of the variance and the tax increase explaining an additional $36.1 \%$ of this variance. However, media explained $64 \%$ of the variance in quitplan.com enrollments, and the tax increase explained an additional $7.6 \%$ of this variance.

Conclusions: Since tax increases occur infrequently, these policy changes must be fully leveraged as quickly as possible to help reduce prevalence.

Keywords: Tobacco Use Cessation, Economics, Taxes, Smoking, Public Health

\section{Background}

Tobacco tax increases are one of the most powerful policy strategies to reduce smoking prevalence [1]. The price elasticity of demand for tobacco is well studied, with a $10 \%$ increase in the real price of cigarettes estimated to reduce smoking prevalence by $1 \%-2 \%$ and consumption by $2 \%-5 \%[2,3]$. Tax increases result in changes in both smoking intentions and behavior. Data from the Minnesota Adult Tobacco Survey show that $65 \%$ of sampled smokers thought about quitting at the time of the 2009 federal

\footnotetext{
* Correspondence: pkeller@clearwaymn.org

'ClearWay Minnesota, 8011 34th Avenue South, Suite 400, Minneapolis, MN 55425, USA

Full list of author information is available at the end of the article
}

tax increase, and $29 \%$ made a quit attempt due to the tax increase [4].

Tax increases also predict quitline service volume. Quitlines are widespread in the United States, Canada, Europe, Australia, New Zealand, and many other countries. In the U.S., state quitlines provide telephone counseling and in many cases, nicotine replacement therapy (NRT), to callers. Following the $2009 \$ 0.62$ federal cigarette tax increase, researchers examined data from 16 state quitlines and found that the tax increase was associated with a $23.5 \%$ increase in quitline utilization from December 2008 to May 2009 compared to December 2007 to May 2008 [5]. Individual states have also reported increases in call volume when their tobacco taxes increased [6-9]. Rates of change varied, 
ranging from more than doubling of intake calls in Montana [7] to an 1,182\% increase in callers in Wisconsin [6]. Promotions and adding new services (e.g., NRT) at the time of the tax increase also positively affected call volumes [6]. However, increases in call volume may be transient. The state of Maine reported substantial increases in callers two weeks before and four weeks after a state tax increase, but then call volumes reverted to the pre-tax increase level [8].

In 2013, Minnesota enacted several large tobacco tax increases. On July 1, 2013, the sales and excise taxes on a pack of cigarettes more than doubled, increasing from $\$ 1.60$ to $\$ 3.35$. The tax on other tobacco products increased from $70 \%$ of wholesale price to $95 \%$ of wholesale price. Additionally, a minimum tax on smokeless tobacco went into effect on January 1, 2014; this tax was equivalent to the cigarette excise tax. This increase resulted in Minnesota's cigarette excise tax being ranked as 7th highest in the nation [10].

ClearWay Minnesota ${ }^{\mathrm{SM}}$ is an independent nonprofit organization established with three percent of Minnesota's settlement with the tobacco industry. Since 2001, ClearWay Minnesota has funded QUITPLAN ${ }^{\circ}$ Services. QUITPLAN Services consists of the QUITPLAN Helpline and quitplan.com. The QUITPLAN Helpline provides multicall telephone counseling and NRT to Minnesotans who are uninsured or underinsured (i.e., no insurance coverage for telephone counseling and/or NRT). Since its inception, the QUITPLAN Helpline has transferred those with health insurance to their health plans' quitlines to receive telephone counseling and medications through their covered benefits. In 2003, ClearWay Minnesota began offering quitplan.com, an online cessation program that is available for all Minnesotans. All QUITPLAN Services are provided at no cost to participants. ClearWay Minnesota actively promotes QUITPLAN Services through a mass media campaign that includes television, radio, billboards, bus sides, and other channels. These efforts have resulted in $71 \%$ of adult Minnesotans reporting having heard of QUITPLAN Services [11].

Several studies have shown a positive relation between paid media and quitline call volume [12-15]. Recognizing that the tax increase would motivate tobacco users to quit, ClearWay Minnesota implemented a six-week paid and earned media campaign to encourage tobacco users to enroll in QUITPLAN Services.

The aims of this study were: (1) to assess the association of a large tobacco tax increase and aggressive media campaign on call volumes, web visits, and enrollments in QUITPLAN Services; (2) to describe the association between the tax increase on enrollments in QUITPLAN Services, controlling for media; (3) to determine whether enrollee characteristics changed during the tax increase and media campaign; and (4) to understand whether enrollees endorsed the tax increase as a reason for quitting. While others have described the association of tax increases on calls and enrollments in quitline services [5-9], no one has examined these associations on both telephone counseling and stand-alone web program enrollments. Since many states, provinces and countries have quitlines, and 32 U.S. states and territories offer web-based cessation services that are either integrated with or independent from the state quitline [16], understanding the association of tax increases on both quitline and online cessation program volumes and enrollments is important to inform resource-allocation decisions. Moreover, to our knowledge, assessing the association of a tobacco tax increase on volumes and enrollments while controlling for media has not been previously reported.

\section{Methods}

\section{Media campaign}

To leverage the July 1, 2013 tax increase, ClearWay Minnesota undertook a six-week statewide paid and earned media campaign. The campaign began on June 24, 2013 and ended on August 4, 2013. The paid media campaign consisted of six weeks of television advertising using an advertisement that had not previously aired in Minnesota, four weeks of announcer-read radio spots promoting QUITPLAN Services, Facebook advertising, and other out-of-home advertising. Television ads were tagged approximately equally with either the QUITPLAN Services telephone number or quitplan.com. Television ad targeted rating points (TRPs; a measure of the breadth of a media campaign in a targeted audience) ranged from 125 to 150/ week. The earned media campaign consisted of a press release and numerous interviews on television and radio statewide promoting QUITPLAN Services.

\section{Data}

In this observational study, data from QUITPLAN Services vendors (National Jewish Health and Alere Wellbeing), and a media database containing information about ClearWay Minnesota's media campaigns, were analyzed.

QUITPLAN Services data consist of administrative data on call volumes, web visits and tobacco user characteristics that are collected when a tobacco user contacts QUITPLAN Services and enrolls in either the QUITPLAN Helpline or quitplan.com. Tobacco user characteristics include demographic information (age, gender, race, ethnicity, sexual orientation, educational level, employment status, insurance status, region of the state the tobacco user resides in), clinical characteristics (pregnancy status, past year receipt of treatment for a mental health condition, whether the participant passed a medical screening to receive nicotine replacement therapy from the Helpline), tobacco use characteristics (type of tobacco used, number of cigarettes per day, time to first cigarette, e-cigarette use at intake, use of menthol cigarettes), and other data pertinent 
to the quitting process (intention to quit in the next 30 days, quit status at intake, quit confidence at intake, quit motivation at intake, whether the participant set a quit date during the intake process). The types of data collected for each service are shown in Tables 1 and 2.

The media database consists of information about all paid media campaigns and selected earned media campaigns conducted by ClearWay Minnesota. Paid media campaigns consist of television, radio, and other types of advertising; earned media campaigns consist of free publicity generated through strategies such as press releases or interviews. Data include campaign type (e.g., quitting, social norm change), ad name, ad campaign start and end dates, and the TRPs for each television and radio ad. Data are summarized weekly. Weekly data about key earned media activities (e.g., Great American Smokeout, Minnesota State Fair) are also included.

\section{Analyses}

Call volume, web visits, enrollments in the QUITPLAN Helpline and quitplan.com, and enrollee characteristics were analyzed for the periods June-August 2012 and June-August 2013 to assess changes at the time of the tax increase and compared to the same period in the previous year. A GLM analysis was conducted to compare monthly volumes from 2012 and 2013. Changes in the number of calls/visits and enrollments, as well as chi-squares and t-tests for differences in participant characteristics, were calculated.

To understand whether people enrolling in QUITPLAN Services reported that the tax increase motivated them to quit, ClearWay Minnesota added a question to the QUITPLAN Services enrollment process in June 2013. Enrollees were asked how much the July 1 st tobacco tax increase affected their decision to quit: a lot, some, a little, or not at all. The number and percent of July and August 2013 enrollees endorsing the tax increase as a motivator was calculated.

To investigate the association of the tax increase on QUITPLAN Services enrollments controlling for the concurrent media campaign, data were analyzed from one year prior to the tax increase to six months following the tax increase (July 2, 2012 through December 29, 2013). The unit of analysis was a week, Monday through Sunday, to conform to the available TRP data for the media campaigns. Since there were 78 weeks in our analyses, a limited set of predictors was analyzed to ensure at least 10 observations per predictor [17]. Two outcome variables were used: the weekly number of Helpline enrollments and the weekly number of quitplan.com enrollments. Each outcome measure was analyzed separately using multivariate regression.

Media campaigns were coded into four predictors: statewide weekly TRPs for (1) QUITPLAN Services radio ads,
(2) QUITPLAN Services TV ads, (3) "Still a Problem" (social norm change) campaign TV ads, and (4) the CDC TIPS campaign. The QuitCash Challenge, a quit-and-win contest sponsored by ClearWay Minnesota, also occurred during the study time period. This contest required that participants sign up online and also encouraged them to enroll in QUITPLAN Services. Previous evaluation data suggested increased web visits and service utilization immediately before and during the contest, so a predictor was created for the contest registration period (March $1-31,2013)$ and a second predictor was created for the contest period (April 1-30, 2013). These predictors were coded as the proportion of days during a week that either contest registration or the contest itself was occurring.

Linear regression analyses were run for each outcome variable. The four media predictors and the two QuitCash Challenge predictors were all forced into the model. Because the association between the tax increase and enrollments has a time limited effect and we did not know what the duration would be or if the effect would start prior to the tax increase, we looked at the 78 residuals (observed minus predicted) from the regression. The residuals were ordered from high to low and the largest positive residuals were examined to determine the weeks in which there was a noticeable change associated with the tax increase. A binary tax impact variable was then coded to indicate the contiguous weeks during which an increase in enrollments occurred. The two linear regressions were then rerun entering the media and QuitCash Challenge predictors in Block 1 and then entering the tax impact predictor in Block 2 . Data were analyzed in 2014 using SPSS version 22.0.0.0. The regression models are displayed in Tables 3 and 4.

The Minnesota Department of Health Institutional Review Board (IRB) reviewed the study and determined it to be exempt (IRB \#14-338).

\section{Results}

Changes in volumes and enrollments

QUITPLAN Services saw a $160 \%$ increase in total calls and web visits combined during this period. Figure 1 illustrates changes in both call volumes and web visits for June-August 2013 compared to June-August 2012.

Calls to the QUITPLAN Helpline nearly doubled (+96\%). Increases varied by month (63\% in June 2013 , $175 \%$ in July 2013, and 56\% in August 2013), with the greatest increase occurring in the month that the tax increase was implemented. Year-over-year monthly differences in call volume were statistically significant for each month (June: $\mathrm{p}=0.041$, July: $\mathrm{p}<0.001$, August: $\mathrm{p}=0.033$ ). By mid-August 2013, QUITPLAN Helpline call volumes were near the same levels as mid-August 2012.

Visits to quitplan.com increased by $173 \%$ in this period. Increases of $48 \%$ in June 2013, 248\% in July 2013, and 256\% in August 2013 were seen. Year-over-year 
Table 1 Changes in QUITPLAN Helpline participant characteristics $(N=1828)$

\begin{tabular}{|c|c|c|c|c|c|}
\hline \multirow[t]{2}{*}{ Characteristic } & \multicolumn{2}{|c|}{$\begin{array}{l}\text { June-August } 2012 \\
(n=696)\end{array}$} & \multicolumn{2}{|c|}{$\begin{array}{l}\text { June-August } 2013 \\
(n=1,132)\end{array}$} & \multirow[t]{2}{*}{$p$-value } \\
\hline & $N$ & $\%$ & $N$ & $\%$ & \\
\hline Gender & & & & & 0.644 \\
\hline Male & 274 & 39.4 & 458 & 40.5 & \\
\hline Female & 422 & 60.6 & 674 & 59.5 & \\
\hline Race & & & & & 0.164 \\
\hline White & 545 & 80.6 & 940 & 85.2 & \\
\hline Black or African American & 75 & 11.1 & 95 & 8.6 & \\
\hline Asian & 8 & 1.2 & 11 & 1.0 & \\
\hline Native Hawaiian or Other Pacific Islander & 2 & 0.3 & 1 & 0.1 & \\
\hline American Indian or Alaska Native & 16 & 2.4 & 24 & 2.2 & \\
\hline Other & 7 & 1.0 & 4 & 0.4 & \\
\hline Multiple races & 23 & 3.4 & 28 & 2.5 & \\
\hline Ethnicity & & & & & 0.938 \\
\hline Hispanic/Latino & 25 & 3.6 & 40 & 3.5 & \\
\hline Non-Hispanic & 667 & 96.4 & 1089 & 96.5 & \\
\hline Sexual orientation & & & & & 0.166 \\
\hline Heterosexual or Straight & 644 & 92.7 & 1076 & 95.1 & \\
\hline Gay or Lesbian & 24 & 3.5 & 28 & 2.5 & \\
\hline Bisexual & 20 & 2.9 & 19 & 1.7 & \\
\hline Other & 7 & 1.0 & 8 & 0.7 & \\
\hline Received counseling/treatment/medication for mental health in past $12 \mathrm{mc}$ & & & & & 0.040 \\
\hline No & 433 & 62.6 & 759 & 67.3 & \\
\hline Yes & 259 & 37.4 & 369 & 32.7 & \\
\hline Education & & & & & 0.932 \\
\hline Less than grade 9 & 10 & 1.4 & 15 & 1.3 & \\
\hline Grade 9 to 11 , no diploma & 56 & 8.1 & 101 & 8.9 & \\
\hline GED & 50 & 7.2 & 77 & 6.8 & \\
\hline High school diploma & 185 & 26.6 & 294 & 26.0 & \\
\hline Some college or university (includes some tech/trade school) & 255 & 36.7 & 399 & 35.3 & \\
\hline College or university degree (including graduate degrees) & 139 & 20.0 & 244 & 21.6 & \\
\hline Employment & & & & & 0.236 \\
\hline Full-time & 191 & 27.6 & 348 & 30.9 & \\
\hline Part-time & 100 & 14.5 & 172 & 15.2 & \\
\hline Not working for pay/other & 400 & 57.9 & 608 & 53.9 & \\
\hline Insurance & & & & & 0.000 \\
\hline Uninsured & 358 & 51.7 & 591 & 52.7 & \\
\hline Medicaid (includes Medical Assistance and Prepaid Medical Assistance Program) & 109 & 15.7 & 93 & 8.3 & \\
\hline Medicare & 137 & 19.8 & 280 & 25.0 & \\
\hline Private & 42 & 6.1 & 91 & 8.1 & \\
\hline Other government (General Assistance or MinnesotaCare) & 26 & 3.8 & 22 & 2.0 & \\
\hline Other - unknown & 21 & 3.0 & 44 & 3.9 & \\
\hline
\end{tabular}


Table 1 Changes in QUITPLAN Helpline participant characteristics $(N=1828)$ (Continued)

\begin{tabular}{|c|c|c|c|c|c|}
\hline Region & & & & & 0.060 \\
\hline Minneapolis/St. Paul & 280 & 40.3 & 394 & 34.8 & \\
\hline Suburban (7-county metro excluding Mpls/St. Paul) & 86 & 12.4 & 148 & 13.1 & \\
\hline Rest of state & 329 & 47.3 & 590 & 52.1 & \\
\hline Pregnancy & & & & & 0.822 \\
\hline Yes & 6 & 1.4 & 7 & 1.0 & \\
\hline Possibly & 2 & 0.5 & 4 & 0.6 & \\
\hline No & 414 & 98.1 & 663 & 98.4 & \\
\hline Tobacco type & & & & & 0.144 \\
\hline Cigarettes (only) & 644 & 93.7 & 1065 & 95.2 & \\
\hline Cigarettes and other tobacco products & 20 & 2.9 & 33 & 2.9 & \\
\hline Other tobacco products (only) & 23 & 3.3 & 21 & 1.9 & \\
\hline e-Cigarette use at intake & & & & & 0.563 \\
\hline No & 668 & 96.0 & 1080 & 95.4 & \\
\hline Yes & 28 & 4.0 & 52 & 4.6 & \\
\hline Cigarettes per day & & & & & 0.560 \\
\hline Less than 10 & 72 & 11.1 & 104 & 9.6 & \\
\hline 10 to 20 & 431 & 66.5 & 725 & 66.9 & \\
\hline 21 or more & 145 & 22.4 & 255 & 23.5 & \\
\hline Menthol cigarette user & & & & & 0.240 \\
\hline No & 489 & 73.6 & 836 & 76.1 & \\
\hline Yes & 175 & 26.4 & 262 & 23.9 & \\
\hline Time to first cigarette & & & & & 0.908 \\
\hline Within 5 minutes & 322 & 50.0 & 542 & 50.0 & \\
\hline 6-30 minutes & 213 & 33.1 & 371 & 34.3 & \\
\hline $31-60$ minutes & 62 & 9.6 & 96 & 8.9 & \\
\hline More than 60 minutes & 47 & 7.3 & 74 & 6.8 & \\
\hline Intend to quit tobacco in next 30 days & & & & & 0.570 \\
\hline No & 17 & 2.5 & 33 & 3.0 & \\
\hline Yes; intend to quit in next 30 days or already quit & 658 & 97.5 & 1076 & 97.0 & \\
\hline Quit status at intake & & & & & 0.054 \\
\hline No; currently using tobacco at intake & 670 & 96.3 & 1107 & 97.8 & \\
\hline Yes; quit at intake & 26 & 3.7 & 25 & 2.2 & \\
\hline Quit confidence at intake & & & & & 0.114 \\
\hline Low $(1-5)$ & 153 & 29.1 & 235 & 25.9 & \\
\hline Medium (6-8) & 290 & 55.2 & 551 & 60.8 & \\
\hline High (9-10) & 82 & 15.6 & 120 & 13.2 & \\
\hline Participant set a quit date during intake call & & & & & 0.568 \\
\hline No & 425 & 61.1 & 676 & 59.7 & \\
\hline Yes & 271 & 38.9 & 456 & 40.3 & \\
\hline Medical screen & & & & & 0.000 \\
\hline Passed screen; no MD consent needed & 590 & 85.4 & 1028 & 91.3 & \\
\hline Failed screen; MD consent needed & 101 & 14.6 & 98 & 8.7 & \\
\hline Average age (stddev) & 44.5 & & 46.0 & & 0.035 \\
\hline
\end{tabular}


Table 2 Changes in quitplan.com participant characteristics $(N=1373)$

\begin{tabular}{|c|c|c|c|c|c|}
\hline \multirow[t]{2}{*}{ Characteristic } & \multicolumn{2}{|c|}{$\begin{array}{l}\text { June-August } 2012 \\
(n=478)\end{array}$} & \multicolumn{2}{|c|}{$\begin{array}{l}\text { June-August } 2013 \\
(n=895)\end{array}$} & \multirow[t]{2}{*}{$p$-value } \\
\hline & $\bar{N}$ & $\%$ & $\bar{N}$ & $\%$ & \\
\hline Gender & & & & & 0.614 \\
\hline Male & 171 & 35.8 & 308 & 34.4 & \\
\hline Female & 307 & 64.2 & 587 & 65.6 & \\
\hline Education & & & & & 0.543 \\
\hline Less than high school & 17 & 3.6 & 31 & 3.6 & \\
\hline High school grad or GED & 95 & 20.4 & 189 & 21.7 & \\
\hline Some college/trade school & 155 & 33.3 & 314 & 36.1 & \\
\hline College graduate & 199 & 42.7 & 337 & 38.7 & \\
\hline Race & & & & & 0.307 \\
\hline White & 435 & 94.8 & 793 & 94.1 & \\
\hline Black or African American & 10 & 2.2 & 27 & 3.2 & \\
\hline Asian & 6 & 1.3 & 12 & 1.4 & \\
\hline Native Hawaiian / Other Pacific Islander & 2 & 0.4 & 0 & 0.0 & \\
\hline American Indian or Alaskan Native & 6 & 1.3 & 11 & 1.3 & \\
\hline Ethnicity & & & & & 0.427 \\
\hline No & 457 & 98.5 & 824 & 97.9 & \\
\hline Yes & 7 & 1.5 & 18 & 2.1 & \\
\hline Insurance & & & & & 0.065 \\
\hline Uninsured & 120 & 25.6 & 191 & 21.7 & \\
\hline Medicaid (includes Medical Assistance and Prepaid Medical Assistance Program) & 19 & 4.1 & 42 & 4.8 & \\
\hline Medicare & 12 & 2.6 & 43 & 4.9 & \\
\hline Private & 250 & 53.3 & 468 & 53.2 & \\
\hline Other government (General Assistance or MinnesotaCare) & 4 & 0.9 & 21 & 2.4 & \\
\hline Other; unknown & 64 & 13.6 & 115 & 13.1 & \\
\hline Has health insurance & & & & & 0.107 \\
\hline No & 120 & 25.6 & 191 & 21.7 & \\
\hline Yes & 349 & 74.4 & 689 & 78.3 & \\
\hline Sexual orientation & & & & & 0.458 \\
\hline Heterosexual & 427 & 93.0 & 795 & 92.3 & \\
\hline Homosexual & 17 & 3.7 & 26 & 3.0 & \\
\hline Bisexual & 10 & 2.2 & 24 & 2.8 & \\
\hline Transgender & 0 & 0.0 & 5 & 0.6 & \\
\hline Other & 5 & 1.1 & 11 & 1.3 & \\
\hline Cigarettes per day & & & & & 0.240 \\
\hline None & 108 & 22.6 & 194 & 21.7 & \\
\hline Low $(<10)$ & 73 & 15.3 & 116 & 13.0 & \\
\hline Moderate (10 to 19$)$ & 143 & 29.9 & 314 & 35.1 & \\
\hline Heavy (20+) & 154 & 32.2 & 271 & 30.3 & \\
\hline Time to first cigarette & & & & & 0.022 \\
\hline Within 5 minutes after waking & 112 & 30.3 & 219 & 31.2 & \\
\hline 6 to 30 minutes after waking & 131 & 35.4 & 300 & 42.8 & \\
\hline 31 to 60 minutes after waking & 86 & 23.2 & 117 & 16.7 & \\
\hline$>60$ minutes after waking & 41 & 11.1 & 65 & 9.3 & \\
\hline
\end{tabular}


Table 2 Changes in quitplan.com participant characteristics $(\mathbf{N}=1373)$ (Continued)

\begin{tabular}{|c|c|c|c|c|c|}
\hline Quit status at intake & & & & & 0.529 \\
\hline No; currently using tobacco & 382 & 81.4 & 728 & 82.8 & \\
\hline Yes & 87 & 18.6 & 151 & 17.2 & \\
\hline Quit confidence at intake & & & & & 0.642 \\
\hline Low (1-5) & 194 & 41.3 & 340 & 38.7 & \\
\hline Moderate (6-8) & 189 & 40.2 & 372 & 42.3 & \\
\hline High (9-10) & 87 & 18.5 & 167 & 19.0 & \\
\hline Quit motivation at intake & & & & & 0.113 \\
\hline Low $(1-5)$ & 44 & 9.4 & 83 & 9.4 & \\
\hline Moderate (6-8) & 222 & 47.2 & 365 & 41.5 & \\
\hline High $(9-10)$ & 204 & 43.4 & 431 & 49.0 & \\
\hline Employment & & & & & 0.394 \\
\hline Full-time & 297 & 63.5 & 589 & 67.9 & \\
\hline Part-time & 65 & 13.9 & 107 & 12.3 & \\
\hline Unemployed/laid-off & 39 & 8.3 & 58 & 6.7 & \\
\hline Not looking for work & 67 & 14.3 & 113 & 13.0 & \\
\hline Average age (stddev) & \multicolumn{2}{|c|}{$35.4(11.4)$} & \multicolumn{2}{|c|}{$38.2(11.6)$} & 0.000 \\
\hline
\end{tabular}

monthly differences in visits were statistically significant in July and August ( $\mathrm{p}<0.001$ in both months); the change seen between June 2012 and June 2013 was not statistically significant $(\mathrm{p}=0.308)$. A second increase in visits to quitplan.com was seen in mid-to-late August in both 2012 and 2013, although the increase was much larger in 2013 compared to 2012. Some of this secondary increase can likely be attributed to additional media activity that began in mid-August to promote quitplan.com.

Figures 2 and 3 illustrate changes in Helpline and quitplan.com enrollments, respectively. Enrollments in QUITPLAN Services increased by $81 \%$ from June to August 2013.

QUITPLAN Helpline enrollments increased by $73 \%$ during this period (38\% in June 2013, $140 \%$ in July 2013 , and 43\% in August 2013). Helpline enrollments mirrored the pattern observed for call volumes, returning to prior year levels by mid-August 2013 (Figure 2). The year-overyear difference in monthly enrollments was statistically significant in July $(\mathrm{p}<0.001)$; the differences seen in June and August were not statistically significant $(\mathrm{p}=0.166$ and $\mathrm{p}=0.149$, respectively).

Enrollments in quitplan.com increased by $93 \%$ from June to August 2013. Increases of 25\% in June 2013, 142\% in July 2013, and 96\% in August 2013 were seen. A second increase in enrollments was observed in mid to late August and mirrored the increase that occurred in 2012 (Figure 3). This difference was statistically significant in July $(\mathrm{p}<0.001)$ and August $(\mathrm{p}<0.009)$; the difference in June was not statistically significant $(p=0.937)$. Some of

Table 3 Regression model, QUITPLAN Helpline enrollments

\begin{tabular}{|c|c|c|c|c|c|}
\hline \multirow[t]{2}{*}{ Model } & \multicolumn{2}{|c|}{ Unstandardized coefficients } & \multirow{2}{*}{$\begin{array}{l}\text { Standardized coefficients } \\
\text { Beta }\end{array}$} & \multirow[t]{2}{*}{$\mathrm{t}$} & \multirow[t]{2}{*}{ Sig. } \\
\hline & B & Std. error & & & \\
\hline (Constant) & 43.924 & 2.439 & & 18.006 & .000 \\
\hline QUITPLAN Radio TRPs & .062 & .025 & .176 & 2.495 & .015 \\
\hline QUITPLAN TV TRPS & .052 & .027 & .145 & 1.928 & .058 \\
\hline Still a Problem TV TRPs & -.011 & .022 & -.034 & -.503 & .616 \\
\hline CDC TIPS2 GRPS & .242 & .067 & .272 & 3.596 & .001 \\
\hline QCC contest & 15.006 & 7.279 & .149 & 2.062 & .043 \\
\hline QCC registration & 3.834 & 7.003 & .042 & .547 & .586 \\
\hline Tax impact window (5 weeks) & 62.190 & 6.759 & .680 & 9.202 & .000 \\
\hline
\end{tabular}

TRPs = Targeted Rating Points; GRPs = Gross Rating Points; QCC = QuitCash Challenge. 
Table 4 Regression model, quitplan.com enrollments

\begin{tabular}{|c|c|c|c|c|c|}
\hline \multirow[t]{2}{*}{ Model } & \multicolumn{2}{|c|}{ Unstandardized coefficients } & \multirow{2}{*}{$\begin{array}{l}\text { Standardized coefficients } \\
\text { Beta }\end{array}$} & \multirow[t]{2}{*}{$\mathrm{t}$} & \multirow[t]{2}{*}{ Sig } \\
\hline & B & Std. error & & & \\
\hline (Constant) & 27.428 & 3.094 & & 8.866 & .000 \\
\hline QUITPLAN Radio TRPs & .220 & .032 & .483 & 6.920 & .000 \\
\hline QUITPLAN TV TRPS & .161 & .033 & .341 & 4.928 & .000 \\
\hline Still a Problem TV TRPs & .007 & .028 & .016 & .241 & .810 \\
\hline CDC TIPS2 GRPS & .060 & .085 & .052 & .703 & .484 \\
\hline QCC contest period & -7.544 & 9.195 & -.058 & -.820 & .415 \\
\hline QCC registration period & 25.404 & 8.833 & .215 & 2.876 & .005 \\
\hline Tax Impact Window (2 weeks) & 55.892 & 12.585 & .304 & 4.441 & .000 \\
\hline
\end{tabular}

TRPs = Targeted Rating Points; GRPs = Gross Rating Points; QCC = QuitCash Challenge.

the secondary increase can likely be attributed to additional media activity that began in mid-August to promote quitplan.com.

\section{Association of tax increase on enrollments controlling for} media

Both media and the tax increase substantially increased enrollments in the QUITPLAN Helpline. The media variables explained $34.0 \%$ of the variance in Helpline enrollments $\left(\mathrm{R}^{2}=0.340\right.$, df $\left.6,71, \mathrm{p}<0.001\right)$. When the tax increase was added, $70.1 \%$ of the variance in Helpline enrollments was explained $\left(R^{2}=0.701\right.$, df $1,70, p<$ 0.001).

A different pattern was seen for quitplan.com enrollments. The media variables explained $64 \%$ of the variance in quitplan.com enrollments $\left(R^{2}=0.636\right.$,

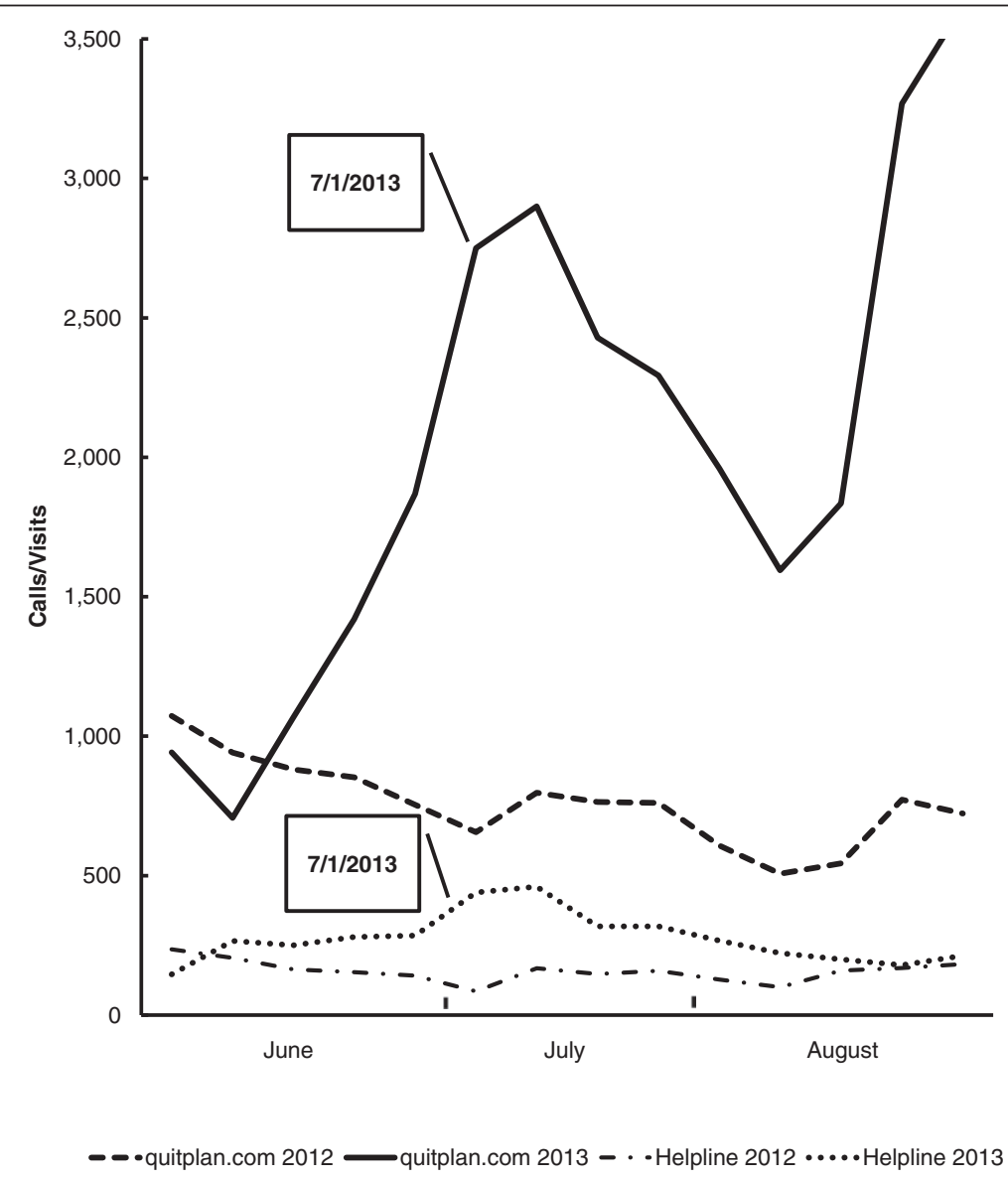

Figure 1 QUITPLAN services call volumes and web visits. 


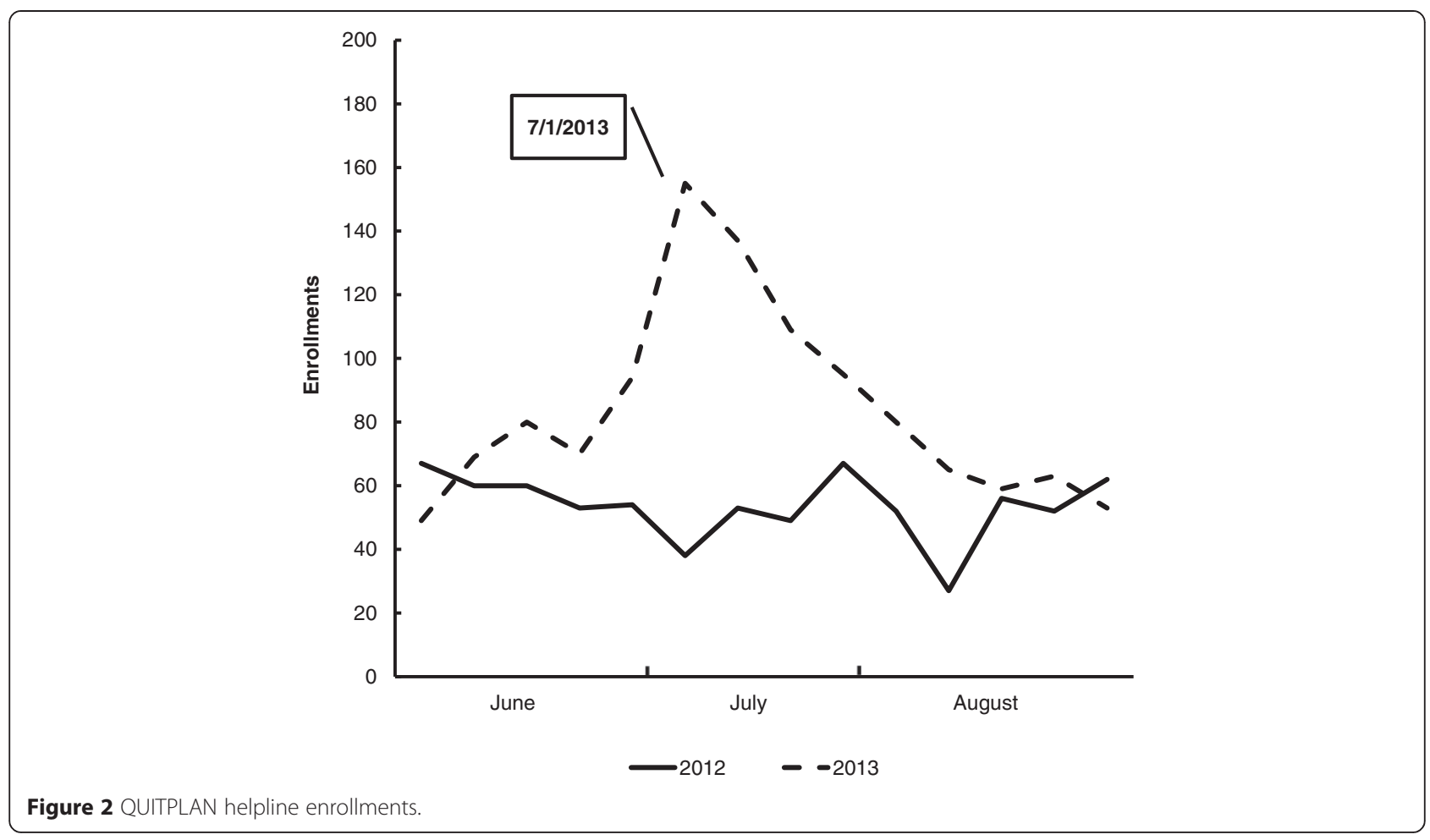

df $6,71, \mathrm{p}<0.001)$. When the tax increase was added, $71.6 \%$ of the variance was explained $\left(R^{2}=0.716\right.$, df $1,70, \mathrm{p}<0.001)$.

\section{Changes in participant characteristics}

Tables 1 and 2 summarize the demographic, tobacco use and other participant characteristics analyzed in this study. Few changes in participant characteristics were observed during June-August 2013 compared to the previous year. The only significant differences $(p \leq 0.05)$ for QUITPLAN Helpline enrollees were: less likely to receive counseling or treatment for mental health conditions in the last 12 months (37.4\% vs $32.4 \%$ ); insurance type (less likely to have Medicaid [15.7\% vs $8.3 \%$ ] and

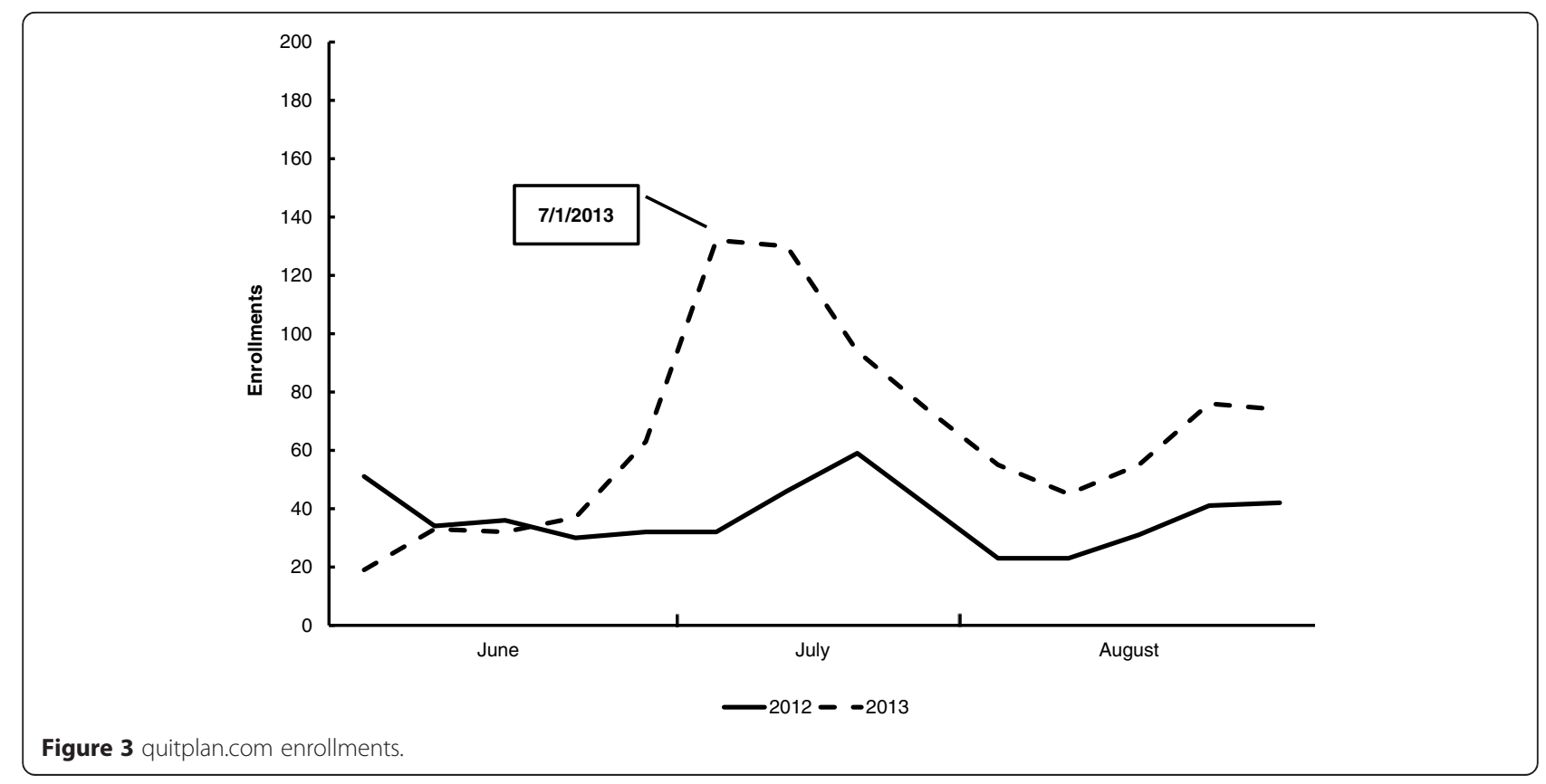


more likely to have Medicare [19.8\% vs $25 \%]$ ); more likely to pass the medical screening to receive NRT $(85.4 \%$ vs 91.3\%); and older (mean age 44.5 vs 46 ) (Table 1). The only significant differences for quitplan.com enrollees were time to first cigarette (more reporting first cigarette between 6 and 30 minutes of waking [35.4\% vs 42.8\%] and fewer reporting first cigarette between 31 and 60 minutes of waking [23.2\% vs $16.7 \%]$ ) and older age (mean age 35.4 vs 38.2) (Table 2).

\section{Tax increase as motivator}

The majority of tobacco users who enrolled in QUITPLAN Services in July and August 2013 endorsed the tax increase as motivating their quit attempt. Among QUITPLAN Helpline enrollees, 52.5\% said that the tax increase affected their decision to quit a lot, $19.6 \%$ reported that it had some effect, $12.4 \%$ reported a little, and $15.5 \%$ reported not at all. Similar results were seen for quitplan.com enrollees, with $49.5 \%$ of enrollees stating it affected their decision to quit a lot, $26.1 \%$ reported it had some effect, $13.2 \%$ reported it had a little impact, 9.4\% reported it did not affect their decision at all, and $1.8 \%$ of responses were missing.

\section{Discussion}

Minnesota's July 2013 cigarette tax increase, combined with an aggressive paid and earned media campaign, was associated with almost a doubling of Helpline calls and nearly a tripling of web visits compared to the same period in 2012. Substantial increases in enrollments in services were also seen. However, this increase was relatively short-lived. While Helpline call volumes and enrollments began to trend upward shortly before the tax increase, they declined to the same levels as 2012 approximately six weeks after the tax increase. This is similar to the pattern reported by Woods and Haskins [8], who observed increases in call volumes two weeks prior to Maine's tobacco tax increase and for four weeks following the tax increase, with call volumes then returning to prior-year levels.

In this study, a second mid-August increase in quitplan.com visits and enrollments was observed. Much of this can be attributed to an annual set of promotional activities that begin in mid-August. These activities include booths at the Minnesota State Fair and extensive earned media promoting QUITPLAN Services. In 2013, two additional promotions were added: a four-week paid radio advertising campaign that was tagged with quitplan.com; and "Together We Quit", a promotion that encouraged smokers to sign up online and quit for the month of September. Registrants were entered into a weekly drawing for a $\$ 100$ gift card. The online registration site was linked to quitplan.com. In 2012, state fair activities were augmented with three weeks of television advertising that promoted quitplan.com and the QUITPLAN Helpline equally.

There is clear evidence that media campaigns as well as tax increases increase quitline call volumes $[6-9,15,18]$. However, in this study and in Maine, this increase was not sustained for a long period of time [8]. To take advantage of tax increases, states should aggressively promote the availability of cessation services through either paid or earned media. These data and data from other states suggest that there is a relatively narrow window of opportunity to increase demand for cessation services. The tobacco control, public health, and healthcare communities must fully leverage tax increases to help increase quit attempts and reduce prevalence. Failure to do so is a missed opportunity to help smokers attempt to quit.

The behavioral economics literature suggests that tobacco tax increases can function as a commitment device for smoking cessation $[19,20]$. Choi and Boyle [4] describe commitment devices as "strategies that reduce the utility of smoking to enable smokers to commit to cessation, potentially through supporting smokers to act on their intention to quit smoking". In this paper, smokers who reported the 2009 federal tax increase as helpful for smoking cessation were more likely to make a quit attempt. The findings from the current study further support the idea that tax increases serve as commitment devices, since approximately half of QUITPLAN Services enrollees said that the state tax increase motivated their quit attempt a great deal. Additionally, data from the 2014 Minnesota Adult Tobacco Survey found that $60.8 \%$ of past-year smokers thought about quitting as a result of the 2013 price increase, and $44.2 \%$ tried to quit [21]. Recognizing the power of tax increases to spur behavior change, combined with data demonstrating that smokers use price-minimizing behaviors to quickly adapt to tax increases [22], there is a need to aggressively promote cessation services at the time of tobacco tax increases. Such promotions capitalize on the potential of tax increases to foster cessation before smokers adopt price-minimizing behaviors and continue to smoke.

Moreover, this study demonstrated the association of the state tax increase on Helpline enrollments and quitplan.com enrollments, controlling for media. To our knowledge, this has not been previously reported. The tax increase and media each explained about the same amount of the variance in Helpline enrollments (34\% and 36.1\%, respectively) and media explained $64 \%$ of the variance in quitplan.com enrollments. The combination of the tax increase and paid media explained over $70 \%$ of the variance in both Helpline and quitplan.com enrollments $(70.1 \%$ and $71.6 \%$, respectively). These findings suggest the need to carefully track paid media, earned media, and other environmental factors to learn what is most effective in 
driving tobacco users to cessation services and how to combine strategies to have additional impact. Further research is warranted to see whether the experience of other states with tax increases, media, and cessation service enrollments are similar to Minnesota's.

Few changes in participant demographic, clinical and tobacco use characteristics were noted after the tax increase (see Tables 1 and 2). Our findings differ from those reported by Bush and Harwell [5,7]. Both of these studies found more variation in caller characteristics after tax increases than were found in this analysis. Looking only at the variables that were comparable across these studies and this analysis, Bush et al. [5] found that more callers after the federal tax increase were white, had less than a high school education, and smoked more cigarettes per day, while Harwell [7] found that callers after Montana's tax increase were more likely to be white, female, younger, and smoked one or more packs of cigarettes per day. In contrast, both Helpline and quitplan.com enrollees were older. Additionally, more quitplan.com enrollees reported that they used cigarettes within 30 minutes of waking. It is unclear why few changes in enrollee characteristics were observed despite increased volumes and enrollments. These findings suggest that an array of communication channels and messages should be used to promote cessation services in order to reach as many diverse audiences as possible.

There are limitations to this study. First, data were available only from QUITPLAN Services, not from the quitlines run by major health plans in Minnesota or other cessation services offered in the state, so the overall association of the tax increase on cessation service utilization in Minnesota is underestimated. Second, other environmental factors that may have influenced smokers to seek cessation services during this time period were not controlled for; however, we were not aware of other significant shifts in the environment that may have accounted for these findings. Third, ClearWay Minnesota tags broadcast advertisements with quitplan.com more frequently than its telephone number (approximately $55 \%-60 \%$ of ads were tagged with quitplan.com during the 78-week period analyzed), which may partially account for broadcast media explaining more of the variation in quitplan.com enrollments compared to the Helpline. It is important to note that all ads that were broadcast during the six weeks around the tax increase were tagged equally with the QUITPLAN Helpline telephone number and quitplan.com. Fourth, ClearWay Minnesota has a yearround media presence promoting QUITPLAN Services, so there was not an opportunity to measure the association of the tax increase without media. Finally, cessation outcomes were not measured in this study.

This analysis identifies several areas for further research. How to optimally leverage tax increases and sustain the interest in and use of quitlines and web-based cessation programs over more than a four to six-week time period is unknown. Research is needed on innovative strategies to maximize the impact of tax increases on both volumes and enrollments in cessation services. Additionally, there is a need to better understand how to effectively engage all types of smokers in the quitting process. This may require carefully examining current cessation service offerings, using technologies such as text messaging to reach different populations of smokers, and partnering with organizations serving diverse communities and persons of low socioeconomic status to facilitate linkages to cessation services. This is essential in order to reach the United States goal in Healthy People 2020 (www.healthypeople.gov/2020/default.aspx) of $80 \%$ of smokers making quit attempts.

\section{Conclusions}

Minnesota's tobacco tax increase and concurrent media campaign was associated with substantial increases in quitline call volumes, web visits, and enrollments in cessation services. Cigarette tax increases are powerful policy changes, and the evidence supporting their association with changing tobacco use patterns is clear. In most states, they occur infrequently. When tax increases do occur, it is incumbent on the tobacco control, public health, and healthcare communities to leverage the power of tax increases and concurrent media campaigns to increase quit attempts, cessation service utilization, and ultimately long-term cessation. Our window of opportunity is narrow, and we must seize it.

\section{Competing interests}

The authors declare that they have no competing interests.

\section{Authors' contributions}

PK designed the study, interpreted analyses and prepared the manuscript. LG and MC collected and analyzed data, and assisted with data interpretation and manuscript preparation. RB and BS assisted with study design, data interpretation and manuscript preparation. All authors read and approved the final manuscript.

\section{Acknowledgments}

The authors would like to thank Randi Lachter and Marietta Dreher (ClearWay Minnesota) as well as Rebecca Lien and Michael Luxenberg (Professional Data Analysts) for their assistance with this evaluation. The authors would also like to acknowledge ClearWay Minnesota's funding of QUITPLAN Services, media campaigns, and staff.

\section{Funding}

This work was funded by ClearWay Minnesota. The contents of this article are solely the responsibility of the authors and do not necessarily represent the official views of ClearWay Minnesota.

\section{Author details}

${ }^{1}$ ClearWay Minnesota, 8011 34th Avenue South, Suite 400, Minneapolis, MN 55425, USA. ${ }^{2}$ Professional Data Analysts, Inc, St. Anthony Main, 219 Main Street SE, Suite 302, Minneapolis, MN 55414, USA.

Received: 2 October 2014 Accepted: 19 March 2015

Published online: 10 April 2015 


\section{References}

1. Levy DT, Boyle RG, Abrams DB. The role of public policies in reducing smoking: the Minnesota SimSmoke tobacco policy model. Am J Prev Med. 2012;43(5 Suppl 3):S179-86. doi:10.1016/j.amepre.2012.07.037.

2. Chaloupka FJ, Peck R, Tauras JA, Xu X, Yurekli A. Cigarette excise taxation: the impact of tax structure on prices, revenues, and cigarette smoking. Cambridge, MA: NBER Working Paper No. 16287; 2010. doi: 10.3386/w16287.

3. Chaloupka FJ, Pacula RL. The Impact of Price on Youth Tobacco Use. In: Burns DM, Bethesda MD, editors. Changing Adolescent Smoking Prevalence, Tobacco Control Monograph 14. U.S. Department of Health and Human Services, Public Health Service, National Institutes of Health, National Cancer Institute; 2001: 193-199. http://cancercontrol.cancer.gov/brp/tcrb/ monographs/14/m14_12.pdf.

4. Choi K, Boyle RG. Minnesota smokers' perceived helpfulness of 2009 federal tobacco tax increase in assisting smoking cessation: a prospective cohort study. BMC Public Health. 2013;13:965. doi:10.1186/1471-2458-13-965.

5. Bush T, Zbikowski S, Mahoney L, Deprey M, Mowery PD, Magnusson B. The 2009 U.S. federal cigarette tax increase and quitline utilization in 16 states. J Environ Public Health. 2012:314740. doi:10.1155/2012/314740. Epub 2012 May 8.

6. Sheffer MA, Redmond LA, Kobinsky KH, Keller PA, McAfee T, Fiore MC. Creating a perfect storm to increase consumer demand for Wisconsin's Tobacco Quitline. Am J Prev Med. 2010;38(3 Suppl):S343-6. doi:10.1016/ j.amepre.2009.11.014.

7. Harwell TS, Lee L, Haugland C, Wilson SM, Campbell SL, Holzman GS, et al. Utilization of a tobacco quit line prior to and after a tobacco tax increase. $J$ Public Health Manag Pract. 2007;13(6):637-41.

8. Woods SS, Haskins AE. Increasing reach of quitline services in a U.S. state with comprehensive tobacco treatment. Tob Control. 2007;16 Suppl 1:i33-6. PMCID: PMC2598522.

9. North American Quitline Consortium. Promoting quitlines during tobacco tax increases. North American Quitline Consortium. 2012. http:// c.ymcdn.com/sites/www.naquitline.org/resource/resmgr/Fact_Sheets/ 100818 FS_tobacco-taxes.pdf. Accessed September 3, 2014

10. Campaign for Tobacco-Free Kids. State Cigarette Excise Tax Rates \& Rankings. Campaign for Tobacco-Free Kids. 2014. http://www.tobaccofreekids.org/research/factsheets/pdf/0097.pdf. Accessed September 3, 2014.

11. Lee JK, Mowery A, Depue J, Luxenberg M, Schillo B. Effectiveness of statewide advertising in promoting the QUITPLAN Services brand. Soc Mark Q. 2013;19(4):207-21. doi:10.1177/1524500413496415.

12. Farrelly M, Hussin A, Bauer U. Effectiveness and cost effectiveness of television, radio and print advertisements in promoting the New York smokers' quitline. Tob Control. 2007;16 Suppl 1:i21-3. PMCID: PMC2598515.

13. Schillo BA, Mowery A, Greenseid LO, Luxenberg MG, Zieffler A, Christenson $M$, et al. The relation between media promotions and service volume for a statewide tobacco quitline and a web-based cessation program. BMC Public Health. 2011;11:939. doi: 10.1186/1471-2458-11-939.

14. Momin B, Neri A, McCausland K, Duke J, Hansen H, Kahende J, et al. Traditional and innovative promotional strategies of tobacco cessation services: a review of the literature. J Community Health. 2014;39(4):800-9. doi: 10.1007/s10900-014-9825-y.

15. Zhang L, Vickerman K, Malarcher A, Mowery P. Intermediate cessation outcomes among quitline callers during a national tobacco education campaign. Nicotine Tob Res. 2014;16(11):1478-86. doi:10.1093/ntr/ntu105. Epub 2014 Jul 8

16. North American Quitline Consortium. Results from the 2012 NAQC annual survey of quitlines. North American Quitline Consortium. 2013. http:// c.ymcdn.com/sites/www.naquitline.org/resource/resmgr/ 2012_annual_survey/oct23naqc_2012_final_report_pdf. Accessed September 3, 2014.

17. Harris R. A primer of multivariate statistics. 2nd ed. New York: Academic; 1985

18. Centers for Disease Control and Prevention. Increases in quitline calls and smoking cessation website visitors during a national tobacco education campaign-March 19-June 10, 2012. MMWR Morb Mortal Wkly Rep. 2012;61(34):667-70. www.cdc.gov/mmwr/preview/mmwrhtml/ mm6134a2.htm.

19. Remler DK. Poor smokers, poor quitters, and cigarette tax regressivity. Am J Public Health. 2004;94(2):225-9.

20. Gruber J, Köszegi B. Tax incidence when individuals are time-inconsistent: the case of cigarette excise taxes. J Public Econ. 2004;88:1959-87. PMCID: PMC1448232.
21. ClearWay Minnesota, Minnesota Department of Health. Minnesota Adult Tobacco Survey: Tobacco Use in Minnesota: 2014 Update. February 2015. http:// www.mntobacco.nonprofitoffice.com/vertical/Sites/\%7B988CF811-1678-459AA9CE-34BD4C0D8B40\%7D/uploads/MATS_2014_Technical_Report_Final_201501-21.pdf. Accessed February 20, 2015.

22. Xu X, Pesko MF, Tynan MA, Gerzhoff RB, Malarcher AM, Pechacek TF. Cigarette price-minimization strategies by U.S. smokers. Am J Prev Med. 2013;44(5):472-6. doi:10.1016/j.amepre.2013.01.019.

\section{Submit your next manuscript to BioMed Central and take full advantage of:}

- Convenient online submission

- Thorough peer review

- No space constraints or color figure charges

- Immediate publication on acceptance

- Inclusion in PubMed, CAS, Scopus and Google Scholar

- Research which is freely available for redistribution 